Research Article

\title{
Molecular assessment of the phylogeny and biogeography of a recently diversified endemic group of South American canids (Mammalia: Carnivora: Canidae)
}

Ligia Tchaicka ${ }^{1}$, Thales Renato Ochotorena de Freitas ${ }^{2}$, Alex Bager $^{3}$, Stela Luengos Vidal ${ }^{4}$, Mauro Lucherini ${ }^{4}$, Agustín Iriarte ${ }^{5}$, Andres Novaro ${ }^{6}$, Eli Geffen ${ }^{7}$, Fabricio Silva Garcez ${ }^{8}$, Warren E. Johnson ${ }^{9}$, Robert K. Wayne ${ }^{10}$ and Eduardo Eizirik ${ }^{8,11}$

${ }^{1}$ Departamento de Química e Biologia, Centro de Educação, Ciências Exatas e Naturais (CECEN), Universidade Estadual do Maranhão (UEMA), São Luís, MA, Brazil.

${ }^{2}$ Departamento de Genética, Instituto de Biociências, Universidade Federal do Rio Grande do Sul (UFRGS), Porto Alegre, RS, Brazil.

${ }^{3}$ Departamento de Biologia, Universidade Federal de Lavras (UFLA), Lavras, MG, Brazil.

${ }^{4}$ Departamento de Biología, Bioquímica y Farmacia, Universidad Nacional del Sur,

Bahía Blanca, Argentina.

${ }^{5}$ Center for Advanced Studies in Ecology \& Biodiversity (CASEB), Pontificia Universidad Catolica \& Fundacion Biodiversitas, Santiago, Chile.

${ }^{6}$ Consejo Nacional de Investigaciones Cientificas y Técnicas, and Wildlife Conservation Society-Argentina, Junín de los Andes, Neuquén, Argentina.

${ }^{7}$ Department of Zoology, Tel Aviv University, Israel.

${ }^{8}$ Laboratório de Biologia Genômica e Molecular, Faculdade de Biociências,

Pontifícia Universidade Católica do Rio Grande do Sul (PUCRS), Porto Alegre, RS, Brazil.

${ }^{9}$ Smithsonian Conservation Biology Institute, Washington, DC, USA.

${ }^{10}$ Department of Ecology and Evolutionary Biology, University of California, Los Angeles, CA, USA.

${ }^{11}$ Instituto Pró-Carnívoros, Atibaia, SP, Brazil.

\begin{abstract}
To investigate the evolution and biogeography of an endemic group of South American foxes, we examined mitochondrial DNA control region sequences for 118 individuals belonging to all six extant species of the genus Lycalopex. Phylogenetic and molecular dating analyses supported the inference that this genus has undergone a very recent and rapid radiation, stemming from a common ancestor that lived ca. 1 million years ago. The Brazilian endemic $L$. vetulus was supported as the most basal species in this genus, whereas the most internal group is comprised by the recently diverged (ca. 350,000 years ago) Andean/Patagonian species L. griseus and L. culpaeus. We discuss the inferred phylogenetic relationships and divergence times in the context of the current geographic distributions of these species, and the likely effects of Pleistocene climatic changes on the biogeography of this group. Furthermore, a remarkable finding was the identification of multiple individuals classified as L. gymnocercus bearing mtDNA haplotypes clearly belonging to $L$. griseus, sampled in regions where the latter is not known to occur. At a minimum, this result implies the need to clarify the present-day geographic distribution of each of these fox species, while it may also indicate an ongoing hybridization process between them. Future testing of this hypothesis with in-depth analyses of these populations is thus a priority for understanding the history, evolutionary dynamics and present-day composition of this endemic Neotropical genus.
\end{abstract}

Keywords: Mitochondrial DNA control region, Lycalopex, Canidae, Carnivora.

Received: July 18, 2015; Accepted: February 11, 2016.

Introduction

Send correspondence to Eduardo Eizirik. Laboratório de Biologia Genômica e Molecular, Faculdade de Biociências, PUCRS, Porto Alegre, RS 90619-900, Brazil. E-mail: eduardo.eizirik@ pucrs.br
The first representatives of the family Canidae entered South America in the late Pliocene and early Pleisto- 
cene, coming from North America through the Panama Isthmus (formed approximately 3 million years ago [mya]), and then radiated to achieve their present diversity (Berta, 1987). Currently there are ten canid species endemic to South America, representing the largest diversity of this family on any continent. This diversity has been attributed to their generalist and opportunistic feeding strategies that utilize vertebrate prey as well as fruits and invertebrates, and their adaptation to a wide variety of habitats (Berta, 1987; Ginsberg and MacDonald, 1990; Wozencraft, 2005).

Of the ten living species of South American canids, eight are often referred to as foxes, and recognized as a monophyletic assemblage comprising the genera Cerdocyon, Lycalopex, and Atelocynus (Wayne et al., 1997; Zrzavy and Ricankova, 2004; Slater et al., 2009; Perini et al., 2010; Prevosti, 2009). These species have similar karyotypes, suggesting a recent divergence $(2 n=74$; $\mathrm{NF}=76$ - A. microtis, L. gymnocercus, L. griseus, $L$. culpaeus, L. sechurae, L. gymnocercus and L. vetulus; $2 \mathrm{n}=74 ; \mathrm{NF}=106-$ Cerdocyon thous [Brum-Zorrila and Langguth, 1980; Wayne et al., 1987; Wayne, 1993]). Although several previous studies have addressed the evolu- tionary relationships among these foxes using morphological and/or molecular data (e.g. Wayne et al., 1997; Lyras and Van Der Geer, 2003; Zrzavy and Ricancova, 2004; Bardeleben et al., 2005; Lindblad-Toh et al., 2005; Prevosti, 2009; Slater et al., 2009; Perini et al., 2010), the resolution of their phylogeny remains elusive, especially with regard to the species belonging to the genus Lycalopex (including Pseudalopex - see below). These canids will be treated here as Lycalopex vetulus (hoary fox), $L$. gymnocercus (pampas fox), L. culpaeus (culpeo), $L$. fulvipes (Darwin's fox), L. griseus (chilla) and L. sechurae (Sechuran fox), following Wozencraft (2005).

Furthermore, the precise geographic range of these species is still not known in full detail, although some broad distributional patterns are well documented (Figure 1). $L$. culpaeus is distributed along the Andes and hilly regions of western South America, from southern Colombia to Tierra del Fuego. L. fulvipes is endemic to costal Chile. L. griseus is widespread in areas of plains and mountains on both sides of the Andes, from northern Chile south to the Strait of Magellan (introduced by humans into the island of Tierra del Fuego in 1953). L. gymnocercus is currently thought to

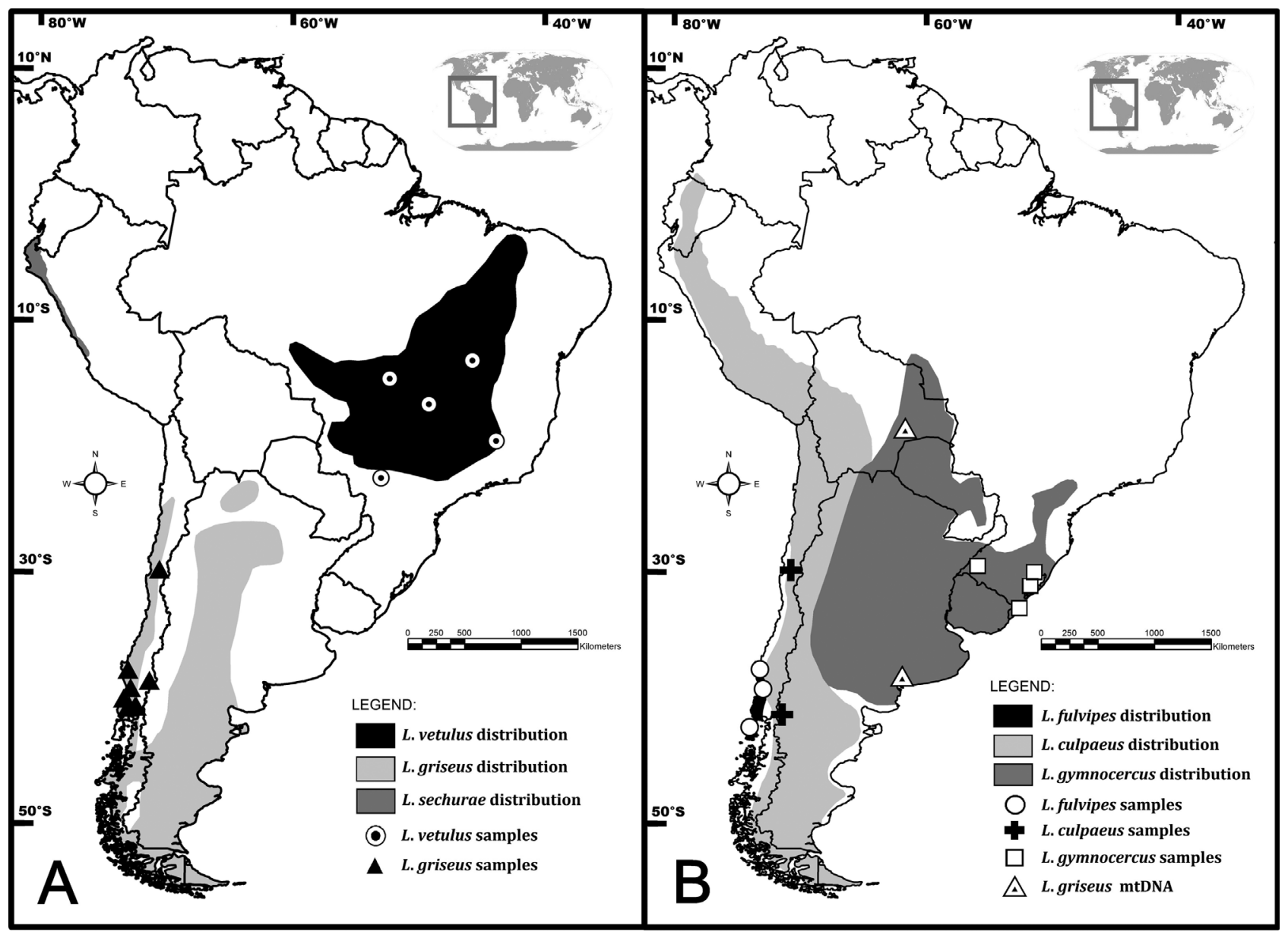

Figure 1 - Maps showing the current geographic distribution of Lycalopex species (modified from Courtenay and Maffei (2004) and approximate sample collection sites. Triangles in panel B indicate sampling localities of individuals initially labeled as L. gymnocercus, but whose mtDNA haplotypes group within the L. griseus clade. Individuals with unknown geographic origin were not included in the map (see Table S1 for more details). 
range from eastern Bolivia and western Paraguay to central Argentina and southern Brazil. L. sechurae occurs on the Pacific coast of Peru and Ecuador. Finally, L. vetulus is endemic to the Cerrado biome and adjacent areas in central Brazil (Sillero-Zubiri et al., 2004).

Several taxonomic schemes for these species have been suggested based on different methods. Langguth (1975), based on ecological and morphological data, suggested two taxa: (i) genus Lycalopex Burmeister, 1854 and (ii) Pseudalopex Burmeister, 1856 as a subgenus of Canis. The former contained only Lycalopex vetulus, the type species for this genus, while the latter contained Canis (Pseudalopex) culpaeus, C. (P.) gymnocercus, C. (P.) griseus and $C .(P$.$) sechurae. Subsequently, Clutton-Brock$ et al. (1976), using morphological and behavioral data, included all these species in the genus Dusicyon C. E. H. Smith, 1839, originally proposed for the now extinct Falkland Island "wolf", D. australis (Wozencraft, 2005). Berta (1987), based on the fossil record and cladistic analyses of morphological data, proposed that the genus Pseudalopex should include $P$. griseus, $P$. gymnocercus, $P$. culpaeus, $P$. vetulus, $P$. sechurae and the extinct species $P$. peruanus. Subsequently, Zunino et al. (1995) grouped $P$. gymnocercus and $P$. griseus into a single species, Lycalopex gymnocercus, supporting the use of Lycalopex as the generic name for L. culpaeus, L. vetulus and $L$. sechurae ( $L$. fulvipes was also considered to be a synonym of L. gymnocercus in that study).

Additional classifications of this group have been suggested (Thomas, 1914; Kraglievich, 1930; Cabrera, 1931; Osgood, 1934; Hough, 1948; Thenius, 1954; Van Gelder, 1978), illustrating the ongoing taxonomic instability in this Neotropical clade throughout the $20^{\text {th }}$ century. U1timately, this confusion is a reflection of the underlying uncertainty regarding the species limits and phylogenetic relationships among these foxes, highlighting the need for additional work focusing on this group. Recent analyses (e.g. Prevosti, 2009; Slater et al., 2009; Perini et al., 2010; Prevosti et al., 2013) have contributed to this debate by exploring larger data sets composed of molecular and/or morphological characters, but still have not conclusively settled these relationships, illustrating the difficulty in achieving a robust phylogeny for this group.

Mitochondrial DNA (mtDNA) segments are useful in evolutionary studies of recent divergence processes in animals, due to their relatively high substitution rate, maternal inheritance, and absence of recombination (Schlötterer, 2004). In spite of limitations derived from these same features, mtDNA segments remain an important source of information in the case of population studies, phylogeography and phylogenetic studies of closely related species, since these rapidly evolving sequences with lower effective population size are often quite informative in attempts to capture recent episodes of taxon divergence. In particular, the fast-evolving mtDNA control region (CR) may be best suited to reconstruct very recent divergence processes involving intra-specific lineages or closely related species, such as the Lycalopex group (whose overall phylogeny has so far not been studied with the CR). Therefore, in this study we employed mtDNA CR sequences to investigate the evolutionary history of Lycalopex foxes and their recent radiation in South America.

\section{Material and Methods}

\section{Biological samples}

We collected biological material from 117 Neotropical canids of the genus Lycalopex (Figure 1 and Table S1), including 32 L. culpaeus, 24 L. gymnocercus, 27 L. vetulus, 6 L. fulvipes, and 28 L. griseus (six of which had been initially identified as L. gymnocercus; see Figure 1 and Discussion). Five Cerdocyon thous individuals (which had been previously sequenced by Tchaicka et al., 2007) were included as outgroups.

Blood samples (preserved in a saturated salt solution of $100 \mathrm{mM}$ Tris, $100 \mathrm{mM}$ EDTA and 2\% SDS) were collected from captive individuals, as well as wild animals captured for field ecology studies. Tissue samples were obtained from road-killed individuals and preserved in $95 \%$ ethanol.

\section{DNA extraction and amplification}

Genomic DNA was extracted from samples using a standard phenol/chloroform protocol (Sambrook et al., 1989). The 5' portion of the mtDNA control region, containing the first hypervariable segment (HVS-I), was amplified by the polymerase chain reaction (PCR; Saiki et al., 1985) using the primers MTLPRO2 and CCR-DR1 (Tchaicka et al., 2007), or H16498 (Ward et al., 1991) as an alternative reverse primer. PCR mixtures consisted of $2 \mu \mathrm{l}$ of $10 \mathrm{X}$ buffer, $1.5 \mathrm{mM} \mathrm{MgCl}_{2}, 0.2 \mathrm{mM}$ of dNTPs, $0.2 \mu \mathrm{M}$ of each primer, 0.75 unit Taq polymerase (Invitrogen) and 1-3 $\mu$ l of empirically diluted template DNA. Thermocycling conditions included 10 initial cycles of "touchdown", with $45 \mathrm{~s}$ denaturing at $94{ }^{\circ} \mathrm{C}, 45 \mathrm{~s}$ annealing at $60-51{ }^{\circ} \mathrm{C}$, and $90 \mathrm{~s}$ extension at $72^{\circ} \mathrm{C}$. This was followed by 30 cycles of $45 \mathrm{~s}$ denaturing at $94{ }^{\circ} \mathrm{C}, 30 \mathrm{~s}$ annealing at $50{ }^{\circ} \mathrm{C}$ and $90 \mathrm{~s}$ extension at $72{ }^{\circ} \mathrm{C}$. Products were examined on a $1 \%$ agarose gel stained with ethidium bromide, purified using shrimp alkaline phosphatase and exonuclease I, sequenced with ABI chemistry and analyzed with an ABI-PRISM 3100 automated sequencer. Sequences generated for this study are deposited in GenBank (accession numbers JX890309 - JX890389). In addition to these sequences, one previously published partial sequence of the mtDNA control region of Lycalopex sechurae (Yahnke et al., 1996) was included in the analyses, so that a total of 118 individuals (representing all known species of this genus) was analyzed. 
Sequence, phylogenetic relationships and population genetics analysis

Sequences were verified and corrected using Chromas (Technelysium) or Sequencher (Gene Codes Inc.), aligned using the ClustalW algorithm implemented in MEGA 6.0 (Tamura et al., 2013) and visually checked. Sites or segments that could not be unambiguously aligned were excluded from all analyses. Initial sequence comparisons and assessments of variability, such as computing the number of variable sites and nucleotide diversity $(\pi$ per nucleotide site, the probability that two randomly chosen homologous nucleotides are different in the sample) were performed in MEGA 6.0 using Kimura 2-parameter distances and 1000 bootstrap replicates. Estimates of gene diversity ( $h$, the probability that two randomly chosen mtDNA lineages were different in the sample) were computed in Arlequin 3.11 (Excoffier et al., 2005) with 10,000 permutations to assess their variance.

We reconstructed the phylogenetic relationships among Lycalopex haplotypes using the Bayesian approach implemented in Beast 1.8.0 (Drummond et al., 2012). We included only complete sequences (i.e. containing no missing data), so as to maximize the stability and reliability of the inferred phylogeny. We estimated the best-fit molecular model of evolution for this data set with Modeltest 3.6 (Posada and Crandall, 1998), using the Akaike Information Criterion. The selected model $(\mathrm{GTR}+\mathrm{G}+\mathrm{I})$ was then incorporated in the analysis. We ran the Markov Chain Monte Carlo (MCMC) process in Beast for 100 million generations, with the data sampled every 1,000 steps, and discarding the initial $10 \%$ as burn-in.

In addition to the phylogenetic analysis, we also investigated the relationships among Lycalopex haplotypes using a median-joining network approach, which was performed with Network 4.6.1.2 (Fluxus Technology). Since this method allows for ancestor-descendant relationships among haplotypes, as well as displays genealogical ambiguities more clearly than a tree-based approach, it is expected to be useful in the analysis of this recently diversified group. Moreover, since our data set included multiple individuals per species, we used this approach to assess species-level monophyly of mtDNA lineages, as well as instances of apparent 'swaps' indicative of errone- ous identification or inter-species hybridization (see Results).

To estimate divergence times within this genus, we used two methods. In the first one, we performed a Bayesian estimation using Beast, assuming an uncorrelated lognormal relaxed molecular clock. This analysis was calibrated with the mean substitution rate $\left(\mu=3.68 \times 10^{-8} /\right.$ year $)$ estimated for the same CR segment in canids by Tchaicka et al. (2007), based on available data from grey wolf and coyote. In the second method, we employed a population-genetic approach based on the equation $\mathrm{d}_{\mathrm{xy}}=2 \mu \mathrm{T}$ (Nei, 1987), using the estimated mtDNA divergence $\left(d_{x y}\right.$ as implemented in Mega, with K2P distances [a simpler model was incorporated here, relative to the Beast analyses, to minimize the variance around parameter estimates]) between species or groups of species, and the same substitution rate mentioned above. The divergence time between mtDNA lineages was calculated considering the $95 \%$ confidence interval $(\mathrm{CI}= \pm 2 \mathrm{SE})$ for all values of $\mathrm{d}_{\mathrm{xy}}$. Using this interval for the calibration node, we obtained low, medium and fast substitution rate estimations $\left(2.02 \times 10^{-8}, 3.68 \times 10^{-8}\right.$ and $5.34 \times 10^{-8} /$ year, respectively), which were then applied to the equivalent $d_{x y}$ interval estimated for each node. This approach allowed a conservative estimate of uncertainty in the dating of these rapid divergences, while providing a robust assessment of their overall temporal framework.

\section{Results}

Sixty-nine different haplotypes were identified with the 588-base pair (bp) segment sequenced for Lycalopex species, defined by 220 variable sites and 193 parsimonyinformative sites. Base composition was biased, with a deficit of guanine $(\mathrm{T}=31.1 \% ; \mathrm{C}=24.6 \% ; \mathrm{A}=26.6 \%$; $\mathrm{G}=17.6 \%$ ). No haplotypes were found to be shared among species. The estimated diversity indices are shown in Table 1 . The phylogenetic analysis generated a tree topology in which several nodes were supported with high posterior probability (Figure 2). The main features of the reconstructed tree were: (i) L. vetulus as the most basal species in the genus Lycalopex; (ii) high support $(\mathrm{PP} \geq 0.9$ ) for the monophyly of every species for which we had more than one individual (L. vetulus, L. gymnocercus, L. culpaeus and $L$. griseus [but see below for a special case within $L$.

Table 1 - Diversity indices (gene $[\mathrm{h}]$ and nucleotide $[\pi]$ diversity) observed in Lycalopex species control region sequences.

\begin{tabular}{lcccccc}
\hline Species & $\mathrm{N}$ & $\mathrm{h}$ & $\Pi$ & $\begin{array}{c}\text { Number of } \\
\text { haplotypes }\end{array}$ & $\begin{array}{c}\text { Number of variable } \\
\text { sites }\end{array}$ & $\begin{array}{c}\text { Number of parsimony } \\
\text { informative sites }\end{array}$ \\
\hline L. culpaeus & 32 & $0.8004+/-0.0407$ & $0.005 \pm 0.002$ & 11 & 16 & 10 \\
L. vetulus & 27 & $0.9323+/-0.0352$ & $0.023 \pm 0.004$ & 16 & 51 & 33 \\
L. griseus & 28 & $0.9398+/-0.0311$ & $0.023 \pm 0.005$ & 17 & 50 & 27 \\
L. gymnocercus & 24 & $0.9723+/-0.0209$ & $0.022 \pm 0.004$ & 17 & 44 & 29 \\
L. fulvipes & 6 & $0.6000+/-0.2152$ & $0.009 \pm 0.004$ & 3 & 5 & 4 \\
\hline
\end{tabular}


griseus]); and (iii) a well-supported, sister-group relationship between L. culpaeus and L. griseus. The single $L$. fulvipes sequence was placed as a sister-group to $L$. gymnocercus (albeit with low support), and both were included in a broader group that also contained L. culpaeus + L. griseus. This clade was in turn the sister-group of the single L. sechurae sequence (see Figure 2).

The haplotype network (Figure 3 ) also revealed interesting patterns, which were broadly consistent with the phylogenetic tree. An interesting difference was the position of L. fulvipes, which was inferred here to be nested within the diversity of L. culpaeus haplotypes. There was evidence of population expansion (i.e. a star-like network, with few mutations between the haplotypes) within species-level clusters. On the other hand, only in the $L$.

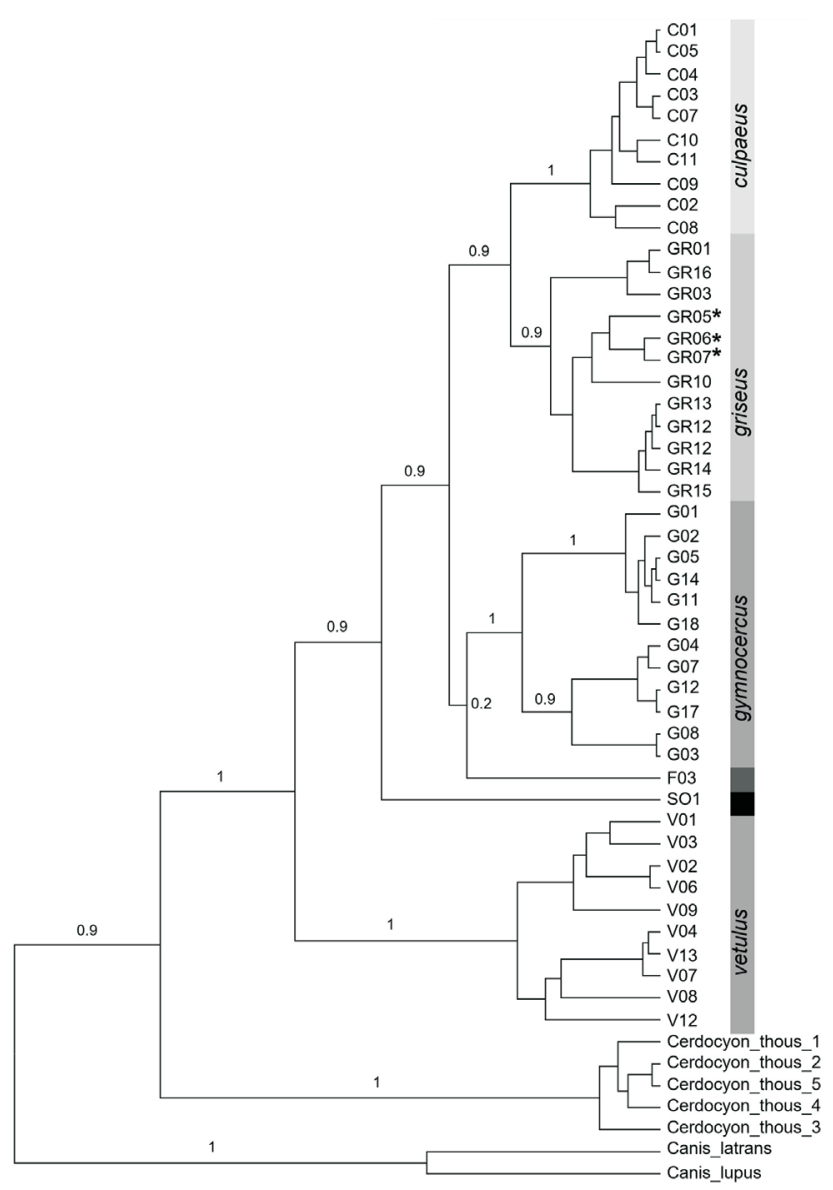

Figure 2 - Bayesian phylogeny (built with the GTR $+\mathrm{G}+\mathrm{I}$ model) of 46 Lycalopex spp. haplotypes based on $588 \mathrm{bp}$ of the mitochondrial DNA control region (only complete sequences were included in the analysis). Five Cerdocyon thous haplotypes were used as outgroups (see Figure S1 for results with additional outgroups). Labels are haplotype identification numbers (as coded in the Table S1: C - L. culpaeus; GR - L. griseus; G L. gymnocercus; F - L. fulvipes; $\mathrm{S}-$ L. sechurae; $\mathrm{V}-$ L. vetulus). Values above branches indicate the Bayesian posterior probability for the adjacent node (support values are shown only for the main clades retrieved in the phylogeny). Asterisks indicate haplotypes deriving from samples initially labeled as $L$. gymnocercus, but whose phylogenetic position was nested within the L. griseus clade. gymnocercus group did we observe sub-groups that showed some evidence of geographic structure (see Figures 2 and 3 ).

Interestingly, both the phylogenetic analysis and the haplotype network indicated that, while the $L$. gymnocercus sequences from southern Brazil did form a monophyletic group, mtDNA lineages from six individuals collected in Bolivia and Argentina, and identified as $L$. gymnocercus in the field (Figure 1, Table S1), were strongly placed as members of the L. griseus clade (Figures 2 and 3 ).

The two methods used to estimate the divergence time between clades yielded broadly similar results. We conservatively estimated that Cerdocyon and Lycalopex diverged between 1-3 mya. L. vetulus seems to have diverged from other Lycalopex species ca. 1 mya, while the youngest event, the divergence between L. culpaeus and L. griseus, is inferred to have occurred very recently, ca. 600,000350,000 years ago (ya) (Table 2).

\section{Discussion}

The phylogenetic analysis resolved with confidence several nodes within this group of canids, indicating that $L$. griseus and L. culpaeus are sister taxa (Figures 2 and 3) that diverged recently, ca. 600,000 - 350,000 ya (Table 2). These results are consistent with a previous molecular study (Yahnke et al., 1996), which reported ca. 250,000500,000 ya as the age of this event. In that study, based on a shorter segment of the mtDNA CR (344 bp), L. griseus and L. culpaeus were not retrieved as reciprocally monophyletic groups, possibly deriving from such a recent divergence that they had not yet achieved complete lineage sorting even for the mtDNA. Our analysis, based on longer sequences, indicates that the two species are well supported as reciprocally monophyletic mtDNA phylogroups.

The low gene diversity, the closely related haplotypes and the absence of substructure in the network analysis support the young origin of L. culpaeus in our sampled area, where Cabrera (1931) considered the occurrence of two subspecies: L. c. culpaeus and L. c. magellanicus. Our results agree with Yahnke et al. (1996) and Guzman et al. (2009) in recognizing a single genetic and morphological group for this species in central-southern Chile.

The results we obtained for $L$. griseus prompted a more careful comparison with the L. gymnocercus data, since some individuals phenotypically identified as $L$. gymnocercus (sampled in Bolivia and Argentina, see Figure 1) were strongly grouped in the L. griseus clade. There are no reliable reports of $L$. griseus occurring in these regions, and information on the precise distribution limits of both species is still scarce. Furthermore, although the presently assumed range of $L$. gymnocercus overlaps with that of L. griseus in several areas, the presence of sympatric populations has never been reported (Lucherini and Luengos Vidal, 2008). One plausible explanation for our 


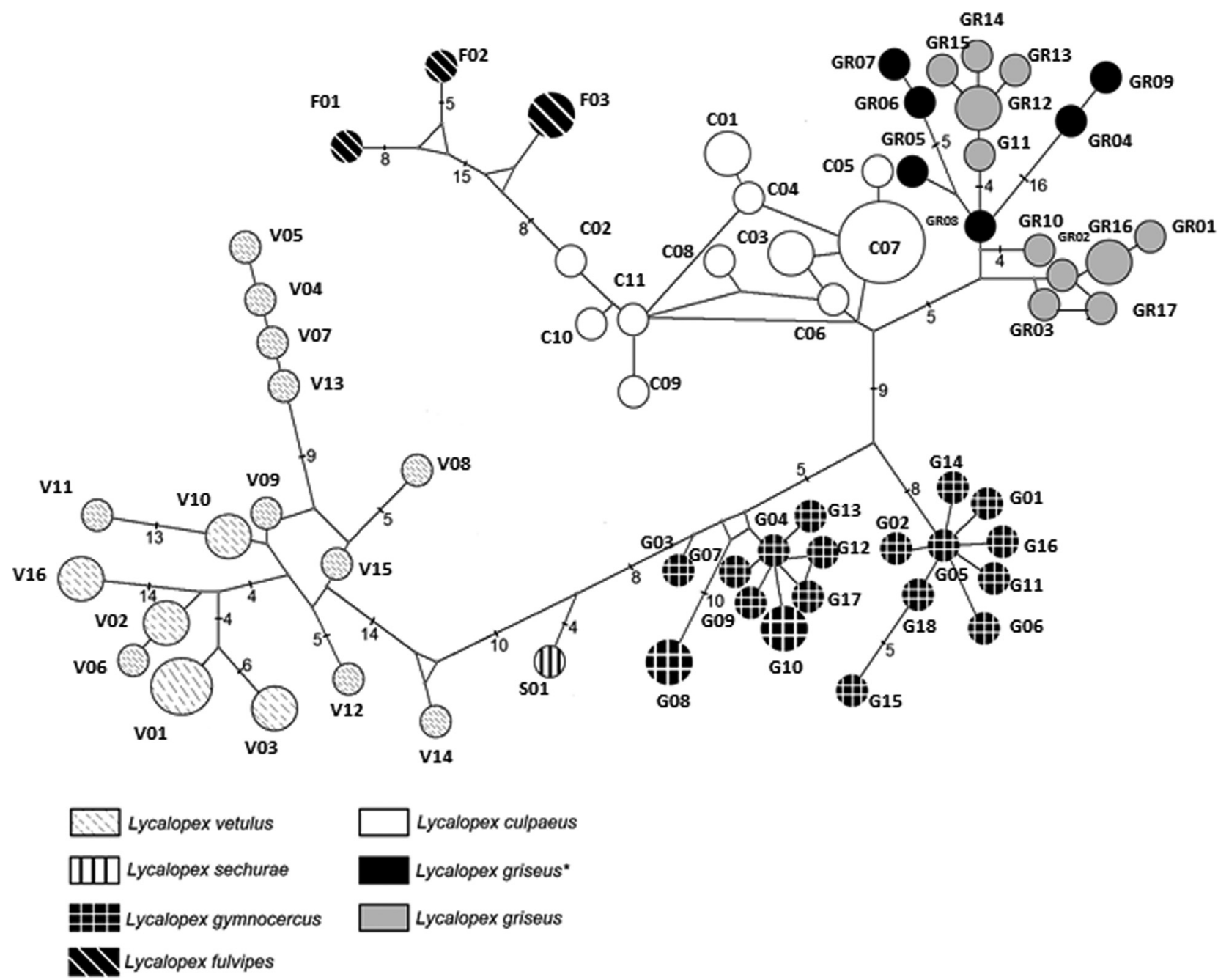

Figure 3 - Median-joining network of Lycalopex mtDNA control region haplotypes. Each circle represents a distinct haplotype (circle area is proportional to the haplotype's global frequency in the sample), color-coded per species as indicated in the internal legend. Numbers located on connecting branches represent the number of substitutions inferred to exist between haplotypes (branches with no number imply a single substitution). Haplotypes shown in black (and marked with an asterisk in the legend) were sampled in six individuals that were initially identified as L. gymnocercus (see text and Table S1 for details).

results is that the areas where our samples were collected may be in fact inhabited by $L$. griseus instead of $L$. gymnocercus. An alternative (non-exclusive) hypothesis is that the presence of L. griseus haplotypes in these regions may be due to hybridization and mtDNA introgression affecting these populations. Each of these hypotheses will be discussed in detail below.

Since pelage color patterns are very similar between these foxes (Zunino et al., 1995), identifying them can be challenging, which suggests that recording errors may have confused historical reports on these species' natural history and the delimitation of their ranges. Studying foxes of the same region, from Bolivia and Paraguay to central Argentina, Zunino et al. (1995) and Prevosti et al. (2013) analyzed pelage characters and cranial measurements of $L$. griseus and L. gymnocercus. These authors observed a clinal variation in size and color, and concluded that these foxes are conspecific (thus calling them L. gymnocercus, the senior name). In contrast, our mtDNA data do not support the merging of these two species into a single unit, since they are not sister-groups in the phylogeny, and seem to represent clearly differentiated evolutionary lineages, at least with respect to their matrilineal history. We thus consider it premature to unite them, and recommend additional taxonomic studies employing an expanded suite of approaches. In particular, it would be important to collect both morphological and molecular data from the same voucher specimens, representing the full geographic range of these species, so that results from the two types of data could be adequately compared.

The hypothesis that secondary hybridization and mtDNA introgression best explains our results should be considered in this context, as it could also account for the clinal pattern of morphological variation observed in some 
Table 2 - Divergence time estimated for Lycalopex groups with a Bayesian dating analysis and a distance-based approach (see text for details).

\begin{tabular}{lcc}
\hline Bayesian Inference & & \\
Clade (basal divergence) & Age (ybp) & $95 \%$ HPD interval \\
\hline Cerdocyon + Lycalopex & $1,951,000$ & $1,173,000-2,767,000$ \\
Lycalopex & $1,353,000$ & $857,000-1,889,000$ \\
L. sechurae + fulvipes + griseus + culpaeus + gymnocercus & $1,075,000$ & $652,000-1,546,000$ \\
L. fulvipes + griseus + culpaeus + gymnocercus & 806,000 & $531,000-1,131,000$ \\
L. fulvipes + gymnocercus & 708,000 & $475,000-1,076,000$ \\
L. culpaeus + griseus & 607,000 & $354,000-900,000$ \\
L. vetulus & 554,000 & $325,000-830,000$ \\
L. gymnocercus & 505,000 & $303,000-750,000$ \\
L. griseus & 438,000 & $246,000-667,000$ \\
L. culpaeus & 292,000 & $139,000-487,000$ \\
\hline Distance-based Inference & & Lower and Upper bound \\
Pair of Clades & Age (ybp) \\
\hline Cerdocyon X Lycalopex & $1,125,000$ & $580,000-2,821,000$ \\
L. vetulus X other Lycalopex & $1,086,000$ & $543,000-2,524,000$ \\
L. sechurae X (L. fulvipes + griseus + culpaeus + gymnocercus $)$ & $552,000-2,301,000$ \\
(L. fulvipes + gymnocercus $)$ X (L. griseus + culpaeus $)$ & 964,000 & $337,000-2,376,000$ \\
L. fulvipes X gymnocercus & 896,000 & $243,000-930,000$ \\
L. culpaeus X griseus & 706,000 & $140,000-965,000$ \\
\hline
\end{tabular}

geographic regions (Zunino et al., 1995; Prevosti et al., 2013). The samples analyzed here that were initially labeled as L. gymnocercus and that bear L. griseus mtDNA might be hybrids between male pampas foxes and female chillas, or further descendants from such a cross. Although inter-species hybridization has so far not been reported for South American foxes, this process has been clearly documented for other canid groups whose members are genetically similar due to recent divergence (e.g. Gottelli et al., 1994; Roy et al., 1994; VonHoldt et al., 2011; Wilson et al., 2012). It is therefore plausible to postulate that secondary admixture may also occur in this recently diversified canid genus, a hypothesis that should be investigated in more detail with expanded sampling in these areas and the use of additional molecular markers.

The exact position of $L$. fulvipes within the internal Lycalopex clades was not completely consistent among our analyses, but the network indicates a well-defined cluster of haplotypes. This fox lives in costal temperate rainforests of Southern Chile, where it inhabits Chiloe Island and also occurs in sympatry with the chilla and culpeo in small continental areas (Medel et al., 1990; Vilà et al., 2004; D'Elia et al., 2013). Initially, it was described as an endemic insular canid and considered a subspecies of continental L. griseus (Redford and Eisenberg, 1992; Wilson and Reeder, 1993; Nowak, 1999). A molecular genetic analysis conducted by Yahnke et al. (1996) revealed that Darwin's fox is a distinct species, forming a monophyletic mtDNA lineage that was a sister taxon to the (L. griseus + L. culpaeus) cluster, from which it would have diverged in the Pleistocene, $c a$. 275,000 to 667,000 ya. These conclusions are corroborated by the present study, as we estimate a divergence time of ca. 700,000 to 800,000 ya between Darwin's fox and its immediately related clades.

The haplotypes of the endemic Brazilian hoary fox $L$. vetulus formed a well-differentiated group, supporting an early divergence of this lineage. Our phylogenetic results strongly supported a basal position for this species within the genus. The estimated time of divergence from the other species was ca. $1-1.3$ mya. Similar values (1.95 mya and 1.3 mya) were obtained for the base of Lycalopex by Slater et al. (2009) and Perini et al. (2010), respectively, using mtDNA (coding regions) and nuclear data. The basal position of $L$. vetulus is in agreement with a phylogeny based on multiple nuclear segments (Lindblad-Toh et al., 2005), although a subsequent study (Perini et al., 2010) reporting the joint analysis of a large supermatrix of molecular and morphological characters retrieved a different resolution (with $L$. sechurae as the most basal species). The full resolution of this portion of the Lycalopex phylogeny will benefit from additional analyses that integrate large data sets and compare topologies derived from different types of sources.

Debate about the proper usage of Lycalopex or Pseudalopex for this group has been ongoing for many years (e.g. Cabrera, 1931; Osgood, 1934; Langguth, 1975; Berta, 1987, 1988; Tedford et al., 1995). If the topological resolution achieved here is affirmed by future studies and 
consolidated for the genus, the basal phylogenetic position of the hoary fox implies that it could be kept in its own genus (Lycalopex), while the other species could move back to Pseudalopex. Alternatively, the whole cluster could be considered a single genus (Lycalopex), as in Wozencraft (2005). Both schemes are compatible with the phylogeny we report here, and this decision will thus be arbitrary. We recommend that this decision be based on criteria such as clade age, morphology, and present usage, which should be established in a broader comparison across all lineages of the family Canidae.

\section{Inferences on the history of South American foxes}

Three different canid invasions from North to South America in the Pliocene or Early Pleistocene have been proposed on the basis of previous inferences of the phylogenetic relationships among extant species. One of them would include the ancestor of the fox group that includes Lycalopex, Cerdocyon, Atelocynus and Dusicyon (Langguth, 1975; Wang et al., 2004). Genetic divergence values reported by Wayne et al. (1997) and Slater et al. (2009) suggest that this divergence occurred before the opening of the Panama land bridge, requiring more than one invasion event.

Contrary to this view, our mtDNA control region data indicate that the divergence between Cerdocyon and Lycalopex took place $c a$. $1-3$ mya, suggesting that this episode of speciation has likely occurred in South America, after immigration of a single ancestor through the Isthmus of Panama. A similar result has also been reported by Perini et al. (2010), who analyzed morphological and molecular (coding genes) characters. In fact, the oldest fossils assigned to Lycalopex (L. gymnocercus) are reported from Argentinean deposits of the Uquian age (2.5 to 1.5 mya), while those of Cerdocyon thous are recorded only from the Lujanian $(800,000-10,000$ ya). Interestingly, there are North American canid fossils reported from the Miocene/Early Pliocene boundary (6-3 mya; Berta, 1987) that have been assigned to the genus Cerdocyon, which would challenge this hypothesis. However, these specimens are very fragmentary, and Prevosti (2009), based on osteological analyses, proposed that North American fossils that were previously assigned to Cerdocyon are, in fact, related to Urocyon. The present dating results, which are congruent with our previous analyses (Tchaicka et al., 2007), support this view that the identification and phylogenetic affinities of these fossils should be reassessed.

It is generally inferred from the fossil record (Langguth, 1975; Berta, 1987) and molecular data (Wayne et al., 1997; Perini et al., 2010) that, subsequently to divergence from Cerdocyon, the diversification of Lycalopex occurred in South America in the Pleistocene. Our results agree with a Pleistocene radiation of Lycalopex (Table 2), indicating that: (i) the oldest extant lineages gave rise to $L$. vetulus, and subsequently to L. sechurae, in the Early-
Middle Pleistocene; (ii) this was followed by the rapid diversification of the griseus-culpaeus-gymnocercusfulvipes clade, in the Middle Pleistocene; and (iii) finally, by the griseus-culpaeus recent split in the Middle-Late Pleistocene.

Extensive environmental changes took place in the Neotropical region during the Pleistocene, which may have influenced this canid radiation. Climatic changes affected the vegetation domains as well as the sea level, producing potential geographic barriers to dispersal or confining species to habitat refuges (Withmore and Prance, 1987; Marroig and Cerqueira, 1997; Eisenberg and Redford, 1999). Canids that had crossed the Panamanian Bridge and possibly dispersed through Andean savanna corridors had expanded their range to Patagonian and Brazilian areas by the Early Pleistocene (Langguth, 1975). At this time, the La Plata-Paraguay depression suffered a marine invasion, potentially connected to the Amazon Basin, possibly isolating a large region of Brazil (Marroig and Cerqueira, 1997). This may account for the isolation of this precursor population into two groups, one located east and the other west of this barrier. The eastern (Brazilian) population would give rise to $L$. vetulus, while the western one would originate the remaining lineages.

During the Pleistocene glacial phases, arid climates dominated some of the equatorial areas and savanna corridors were broken. Some mammal species that became restricted to tropical regions may have become savannaadapted, and now occur in areas consisting of Cerrado habitat (Whitmore and Prance, 1987; Eisenberg and Redford, 1999). This may be the case of the Hoary fox: its small carnassials, wide crushing molars and the exceptionally large auditory bulla (Clutton-Brock et al., 1976) suggest adaptations to a predominantly insectivorous diet. Their preference for insects now allows them to partition food resources and to coexist with other sympatric canids such as the maned wolf (Chrysocyon brachyurus) and the crabeating fox (Cerdocyon thous) (Juarez and Marinho-Filho, 2002).

The center of the Lycalopex radiation has been proposed by Berta (1987) to have been in central Argentina, whereas Langguth (1975) suggested that central Brazil was the most likely region. These two hypotheses are reconciled here, since the main burst of speciation in this group probably did take place in Argentina or Chile (gymnocercusfulvipes-[griseus+culpaeus]). As suggested by Yahnke et al. (1996), L. fulvipes may represent a set of relict populations of a once more widely distributed species, whose phylogenetic affinities within this group are still not completely settled. Future work should use increased sampling of individuals and characters to attempt to clarify this issue so that a more complete biogeographic inference can be devised for this group. Moreover, the prospect of fully resolving this recent South American radiation promises to shed light on some of the processes shaping the composition of 
mammalian communities in this region during the Pleistocene.

\section{Acknowledgments}

The authors wish to thank all the people and institutions listed in the Supplementary data, who provided biological samples used in this study. We are also grateful to Centro Nacional de Pesquisas para a Conservação de Predadores Naturais - CENAP / ICMBio, Instituto Pró-Carnívoros and $\mathrm{CNPq}$ for having supported this project, to Klaus Koepfli for help in data collection and to Lucas Gonçalves da Silva for help with the preparation of one of the figures.

\section{References}

Bardeleben C, Moore R L and Wayne RK (2005) A molecular phylogeny of the Canidae on six nuclear loci. Mol Phylogenet Evol 37:815-831.

Berta A (1987) Origin, diversification and zoogeography of the South American Canidae. Fiel Zool 39:455-471.

Berta A (1988) Quaternary evolution and biogeography of the large South American Canidae (Mammalia, Carnivora). Geol Sci 132:1-149.

Brum-Zorrila N and Langguth A (1980) Karyotype of South American Pampas fox Pseudalopex gymnocercus (Carnivora, Canidae). Experientia 36:1043-1044.

Cabrera A (1931) On some South American canine genera. J Mamm 12:54-67.

Clutton-Brock J, Cobert GB and Hills MA (1976) A review of the family Canidae with a classification by numerical Methods. Bull British Mus (Nat Hist) Zool 2:117-199.

Courtenay O and Maffei L (2004) Cerdocyon thous (Linnaeus, 1766). In: Hoffmann M and Sillero-Zubiri C (eds) Canid Action Plan. IUCN Publications, Gland, pp. 67.

D’Elia G, Ortloff A, Sánchez P, Guinez B and Varas V (2013) A new geographic record of endagered Darwin's fox Lycalopex fulvipes (Carnivora, Canidae): Filling the distributional gap. Rev Chilena Hist Nat 86:485-488.

Drummond AJ, Suchard MA, Xie D and Rambaut A (2012) Bayesian phylogenetics with BEAUti and the BEAST 1.7. Mol Biol Evol 29:1969-1973.

Eisenberg JF and Redford KH (1999) Mammals of the Neotropics: The Central Neotropics. The University of Chicago Press, Chicago, 609 p.

Excoffier L, Laval G and Schneider S (2005) Arlequin version 3.0: An integrated software package for population genetics data analysis. Evol Bioinform Online 1:47-50.

Ginsberg JR and MacDonald DW (1990) Foxes, Wolves, Jackals, and Dogs: An Action Plan for the Conservation of Canids. IUCN Publications, Gland, $90 \mathrm{p}$.

Gottelli D, Sillero-Zubiri C, Applebaum GD, Roy MS, Girman DJ, Garcia-Moreno J, Ostrander EA and Wayne RK (1994) Molecular genetics of the most endangered canid: The Ethiopian wolf Canis simensis. Mol Ecol 3:301-312.

Guzman J, Delia G and Ortiz J C (2009) Variacion geografica del zorro Lycalopex culpaeus (Mammalia Canidae) en Chile: Implicaciones taxonomicas. Rev Biol Trop 57:421-432.

Hough JR (1948) The auditory region in some members of the Procyonidae, Canidae e Ursidae. Its significance in the phylogeny of the Carnivora. Bull Am Mus Nat Hist 92:70-118.
Juarez KM and Marinho-Filho J (2002) Diet, habitat use, and home ranges of sympatric canids in central Brazil. J Mamm 83:925-933

Kraglievich L (1930) Craniometría y classificacion de los canidos sudamericanos especialmente los Argentinos actuales y fósiles. Physis 10:35-73.

Langguth A (1975) Ecology and evolution in the South American canids. In: Fox MW (ed) The Wild Canids. Litton Educational Publishing, New York, pp 92-206.

Lindblad-Toh K, Wade CM, Mikkelsen TS, Karlsson EK, Jaffe DB, Kamal M, Clamp M, Chang JL, Kulbokas III EJ, Zody MC, et al. (2005) Genome sequence, comparative analysis and haplotype structure of the domestic dog. Nature 438:803-819.

Lucherini M and Luengos Vidal E (2008) Lycalopex gymnocercus (Carnivora, Canidae). Mamm Species 820:1-9.

Lyras GA and Van Der Geer AAE (2003) External brain anatomy in relation to the phylogeny of Caninae (Carnivora: Canidae). Zool J Linn Soc 138:505-522.

Marroig G and Cerqueira R (1997) Plio-Pleistocene South American history and the Amazon lagoon hypothesis: A piece in the puzzle of Amazonian diversification. J Comp Biol 2:103-119.

Medel RG, Jiménez JE, Jaksic FM, Yáñez JL and Armesto JJ (1990) Discovery of a continental population of the rare Darwin's fox, Dusicyon fulvipes (Martin,1837) in Chile. Biol Cons 51:71-77.

Nei M (1987) Molecular Evolutionary Genetics. Columbia University Press, New York, 512 p.

Nowak RM (1999) Walker's Mammals of the World. The Johns Hopkins University Press, Baltimore, 560 pp.

Osgood WH (1934) The genera and subgenera of South American Canidae. J Mamm 15:45-50.

Perini FA, Russo CAM and Schrago CG (2010) The evolution of South American endemic canids: A history of rapid diversification and morphological parallelism. J Evol Biol 23:311-322.

Posada D and Crandall KA (1998) Modeltest: Testing the model of DNA substitution. Bioinformatics 14:817-818.

Prevosti FJ (2009) Phylogeny of the large extinct South American Canids (Mammalia, Carnivora, Canidae) using a "total evidence' approach. Cladistics 25:1-26.

Prevosti FJ, Segura V, Cassini G and Martin GM (2013) Revision of the systematic status of Patagonian and Pampean gray foxes (Canidae: Lycalopex griseus and L. gymnocercus) using 3d geometric morphometrics. Mast Neot 20:289-300.

Redford KH and Eisenberg JF (1992) Mammals of the Neotropics: The Southern Cone. The University of Chicago Press, Chicago, $430 \mathrm{p}$.

Roy M, Geffen E, Smith D, Ostrander E and Wayne R (1994) Patterns of differentiation and hybridization in North American wolf like canids, revealed by analysis of microsatellite loci. Mol Biol Evol 11:553-570.

Saiki RK, Scharf S, Faloona F, Mullis KB, Horn GT, Erlich HA and Arnheim N (1985) Enzymatic amplification of betaglobin genomic sequences and restriction site analysis for diagnosis of sickle cell anemia. Science 230:1350-1354.

Sambrook J, Fritsch EF and Maniatis T (1989) Molecular Cloning: A Laboratory Manual. $2^{\text {nd }}$ edition. Cold Spring Harbor Laboratory Press, New York, 980 p. 
Schlötterer C (2004) The evolution of molecular markers - Just a matter of fashion? Nat Rev Genet 5:63-69.

Sillero-Zubiri C, Hoffmann M and MacDonald DW (2004) Canids: Foxes, Wolves, Jackals and Dogs: Status Survey and Conservation Action Plan. 2nd edition. IUCN Canid Specialist Group, Switzerland and Cambridge, 123 p.

Slater GJ, Thalmann O, Leonard JA, Schweizer RM, Koepfli K, Pollinger JP, Rawlence NJ, Austin JJ, Cooper A and Wayne RK (2009) Evolutionary history of the Falklands wolf. Curr Bio 119:20:937-938.

Tamura K, Glen Stecher, Daniel Peterson, Alan Filipski and Sudhir Kumar (2013) MEGA6: Molecular Evolutionary Genetics Analysis version 6.0. Mol Biol Evol 30:2725-2729.

Tchaicka L, Eizirik E, Oliveira TG, Cândido Jr. JF and Freitas TRO (2007) Phylogeography and population history of the crab-eating fox (Cerdocyon thous). Mol Ecol 16:819-838.

Tedford RH, Taylor BE and Wang X (1995) Phylogeny of the Caninae (Carnivora: Canidae): The living taxa. Am Mus Novitates 3146:1-37.

Thenius E (1954) Zur Abstammung der Rotwölfe (Gattung Cuon Hodgson). Österr Zool Z 5:378-387.

Thomas O (1914) The generic and subgeneric names of the South American Canidae. Ann Mag Nat Hist 8:350-352.

Van Gelder RG (1978) A review of Canidae classification. Am Mus Novitates 2646:1-10.

Vilà C, Leonard JA, Iriarte A, O'Brien SJ, Johnson WE and Wayne RK (2004) Detecting the vanishing populations of the highly endangered Darwin's fox, Pseudalopex fulvipes. Animal Cons 7:147-153.

VonHoldt BM, Pollinger JP, Earl DA, Knowles JC, Boyko AR, Parker H, Geffen E, Pilot M, Jedrzejewski W, Jedrzejewska $\mathrm{B}$, et al. (2011). A genome-wide perspective on the evolutionary history of enigmatic wolf-like canids. Genome Res 21:294-1305.

Wang X, Tedford RH, Van Valkenburgh B and Wayne RK (2004) Phylogeny, classification and evolutionary ecology of the Canidae. In: Sillero-Zubiri C, Hoffmann $M$ and Macdonald DW (eds) Canids: Foxes, Wolves, Jackals and Dogs: Status Survey and Conservation Action Plan. 2nd edition. IUCN Canid Specialist Group, Switzerland and Cambridge, pp 300.

Ward RH, Frazier BL, Dew-Jager K and Pääbo S (1991) Extensive mitochondrial diversity within a single Amerindian tribe. Proc Natl Acad Sci USA 88:8720-8724.
Wayne RK, Geffen E, Girman DJ, Koepfli KP, Lau LM and Marshall CR (1997) Molecular systematics of the Canidae. Syst Biol 46:622-653.

Wayne RK (1993) Molecular evolution of the dog family. Trends Genet 6:218-224.

Wayne RK, Nash WG and O'Brien SJ (1987) Chromosome evolution of the Canidae. II. Divergence from the primitive carnivore karyotype. Cytogenet Cell Genet 44:134-141.

Wilson PJ, Rutledge LY, Wheeldon TJ, Patterson BR and White BN (2012) Y-chromosome evidence supports widespread signatures of three-species Canis hybridization in eastern North America. Ecol Evol 2:2325-2332.

Wilson DE and Reeder DM (1993) Mammal Species of the World: A Taxonomic and Geographic Reference. 2nd edition. Smithsonian Institution Press, Washington DC, 346 p.

Whitmore TC and Prance GT (1987) Biogegraphy and Quaternary History in Tropical America. Oxford University Press, New York, 200 p.

Wozencraft WC (2005) Order Carnivora. In: Wilson DE and Reeder DM (eds) Mammals Species of the World. London Smithsonian Institution Press, London, 1100 p.

Yahnke CJ, Johnson WE, Geffen E, Smith D, Hertel F, Roy MS, Bonacic CF, Fuller TK, Van Valkenburgh B and Wayne RK (1996) Darwin's fox: A distinct endangered species in a vanishing habitat. Cons Biol 10:366-375.

Zrzavy J and Ricankova V (2004) Phylogeny of recent Canidae (Mammalia, Carnivora): Relative reliability and utility of morphological and molecular datasets. Zool Scripta 33:311-333.

Zunino G, Vaccaro O, Canevari M and Gardner A (1995) Taxonomy of the genus Lycalopex (Carnivora, Canidae) in Argentina. Proc Biol Soc 108:729-747.

\section{Supplementary Material}

The following online material is available for this article:

Table S1 - Samples analyzed in the present study.

Figure S1 - Phylogenetic relationships among Lycalopex spp.

Associate Editor: Louis Bernard Klaczko

License information: This is an open-access article distributed under the terms of the Creative Commons Attribution License (type CC-BY), which permits unrestricted use, distribution and reproduction in any medium, provided the original article is properly cited. 